\title{
Bilješka o osječkoj galeriji: od Galerije slika do Muzeja likovnih umjetnosti
}

\section{Zec, Daniel}

Source / Izvornik: Institucije povijesti umjetnosti : zbornik 4. kongresa hrvatskih povjesničara umjetnosti, 2019, 43 - 50

Conference paper / Rad u zborniku

Publication status / Verzija rada: Published version / Objavljena verzija rada (izdavačev PDF)

https://doi.org/10.31664/z4khpu.06

Permanent link / Trajna poveznica: https://urn.nsk.hr/urn:nbn:hr:254:901876

Rights / Prava: Attribution 4.0 International/Imenovanje 4.0 međunarodna

Download date / Datum preuzimanja: 2023-04-26

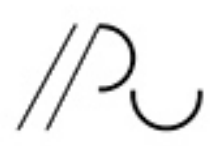

INSIITUTR ZA POVIJEST UMJETNOST
Repository / Repozitorij:

PODEST - Institute of Art History Repository

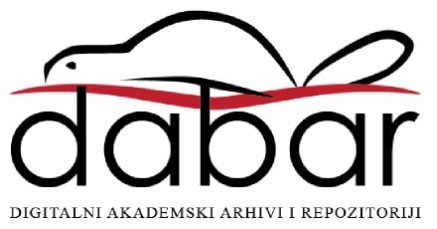




\section{Bilješka o osječkoj galeriji: od Galerije slika do Muzeja likovnih umjetnosti}

\section{Uvod}

U tekstu što slijedi sažeto se prikazuje povijest Galerije, odnosno Muzeja likovnih umjetnosti u Osijeku, ${ }^{1}$ te se razmatra njegova uloga institucije povijesti umjetnosti u gradu, regiji i u nacionalnim okvirima.

O povijesti osječke Galerije do danas objavljeno je više članaka u stručnim časopisima i knjigama, a pisali su ih protagonisti njezina stvaranja i rada, poglavito njezini osnivači, kustosi i ravnatelji. ${ }^{2}$ Najviše tekstova o Galeriji napisao je i objavio Antun Bauer, ${ }^{3}$ a osobito obuhvatan tekst o njezinoj povijesti i djelovanju zahvaljujemo Stjepanu Brlošiću, dugogodišnjem ravnatelju ustanove. ${ }^{4}$

\section{Počeci: u okrilju Muzeja Slavonije}

Postanak Muzeja, donedavno Galerije likovnih umjetnosti u Osijeku, vezan je uz osječki Muzej Slavonije, osnovan I877., ${ }^{5} \mathrm{u}$ okviru kojega je Galerija tijekom nastanka i formiranja administrativno i fizički egzistirala jedanaest godina. No od sama početka ona nije bila u funkciji zbirke slika i skulptura Muzeja Slavonije, niti se takvom nazivala, već je imala stanovitu samostalnost, o čemu svjedoči odluka o njezinu osnivanju iz ı94o. godine, a konačno i sam njezin prvobitni naziv, koji je dugo vremena ostao u uporabi-Galerija slika. U institucionalnom okrilju osječkoga Muzeja razvijala se postupno, od I94I. pa do I952. godine, kada se izdvojila prostorno, a I954. i institucionalno, u samostalnu muzejsku ustanovu.

Jedan od inicijatora, pokretač i organizator-zapravo, istinski utemeljitelj osječke Galerije slika-bio je Antun Bauer (IgII. 200o.), povjesničar umjetnosti, osnivač i tadašnji ravnatelj Gipsoteke u Zagrebu. Na prijedlog Antuna Bauera Galerija je osnovana 1940. u sklopu Gradskoga muzeja u Osijeku, a temelj $\mathrm{u}$ procesu njezina stvaranja bila je vrijedna donacija umjetnina gradu Osijeku (za osnivanje Galerije) iz Zagreba, koje

\section{Daniel Zec}

Muzej likovnih umjetnosti, Osijek daniel.zec@mlu.hr

http://orcid.org/oooo-oooi-6o75-I453
I Od osnutka do danas osječka je Galerija mijenjala ime: Galerija slika, odnosno Moderna galerija slika (I940./r94I.); Galerija slika u Osijeku (I954.); Galerija likovnih umjetnosti u Osijeku (I966.); Muzej likovnih umjetnosti (20I4.)

2 JOVAN GOJKOVIĆ, Galerija slika u Osijeku, u: Bulletin Instituta za likoune umjetnosti JAZU, Zagreb, god. I, 3-4 (I953.), 54; JOVAN GOJKOvić, Galerija slika u Osijeku, u: Osječki zbornik, Osijek, Muzej Slavonije, 4 (I954.), I67-I68; DANICA PINTEROviĆ, O razvoju osječkog muzeja, u: Osječki zbornik, Osijek, Muzej Slavonije , 6 (I958.), 7-22; JELICA AMBRUŠ, Povijest Galerije likovnih umjetnosti u Osijeku, u: Vodič stalnog postava Galerije likounih umjetnosti u Osijeku, Osijek, Galerija likovnih umjetnosti, I978.; VESNA BURIć, Prof. dr. Bauer i Osijek, u: Glasnik slavonskih muzeja, Vukovar, 45 (I982.), 43-45.; VLASTIMIR KUSIK, Galerija likovnih umjetnosti, Osijek, u: Informatica Museologica, I-4 (I986.), 78-80; VLASTIMIR KUSIK, Prvi stalni postav i dvije izložbe osječke Galerije slika, u: Galerija likounih umjetnosti Osijek, monografija - zbornik, Osijek, GLUO, I987., 3I-34; OTO ŠVAJCER, Umetak XII (izložbeni prostori u Osijeku - Galerija), u: Oto Švajcer, Likouna kronika Osijeka I85o-I969. godine, Osijek, GLUO, I99I., 207-208; JELICA AMBRUŠ, Galerija likovnih umjetnosti u Osijeku, u: Muzeologija, 3I (I994.), $70-73$.

3 ANTUN BAUER, Ad "Galerija slika u Osijeku”, Zagreb, vlastito izdanje, umnoženo, I952. (MDC, knjižnica, Zbirka Bauer); 367 ; ANTUN BAUER, Novo otvorenje Galerije slika u Osijeku, u: Vijesti Društva muzejsko-konzervatorskih naučnih radnika NRH, Zagreb, vol. I, 5/6 (I952.), 42; ANTUN BAUER, Osnivanje Galerije umjetnina u Osijeku: nakon referata na plenumu u Galeriji u Osijeku 26. IV. 56, I956., MDC; ANTUN BAUER, Otvorenje Galerije likovnih umjetnosti u Osijeku, u: Vijesti muzealaca i konzervatora Hrvatske, Zagreb, vol. I4, I (I965.), I6; ANTUN BAUER, Osnivanje Galerije slika u sklopu Gradskog muzeja u Osijeku, u: Osječki zbornik, Osijek, Muzej Slavonije, I7 (I979.); ANTUN BAUER, Malvina Hermann Osijek: donator Gradskom muzeju za osnivanje Galerije u Osijeku I939-4I., I982., MDC, knjižnica, Zbirka Bauer.

4 STJEPAN BRLOŠIĆ, Kronika Galerije likovnih umjetnosti, Osijek, u: Galerija likounih umjetnosti Osijek, monografija-zbornik, Osijek, GLUO, I987., II-30.

5 Muzej Slavonije od osnutka mijenjao je ime: Muzej sl. i kr. grada Osijeka (1877.); Hrvatski državni muzej (I942.); Muzej Slavonije (I947.). 
su zahvaljujući Baueru I940. i I94I. ušle u osječki muzej. Uz Bauera, koji je poduzeo konkretne korake na planu osnivanja Galerije, važnu ulogu u njezinu pokretanju imali su Franjo Buntak i nakon njega Josip Bösendorfer kao kustosi i ravnatelji osječkog Gradskog muzeja te Arheološki klub Mursa, odnosno Društvo prijatelja starina Mursa iz Osijeka.

Predlažući osnivanje Galerije u Osijeku, Antun Bauer imenovao ju je specifičnim nazivom Moderna galerija. Taj je naziv doista odgovarao prvotno zamišljenoj koncepciji njezina fundusa i postava, koji se sastojao većinom iz djela hrvatskih umjetnika moderne. Uz taj naziv uvriježio se i naziv Galerija slika, koji je ostao u primjeni kao službeni naziv ustanove sve do Ig66. godine.

Galerija je službeno otvorena u prostorijama Gradskoga muzeja I6. studenoga I94I., „kao posebni odjel Gradskoga muzeja”. Autor tog prvog postava Galerije bio je sam Antun Bauer, a njezin prvi kustos bio je osječki slikar Stjepan Macanić (IgII. I945.). Bio je to prvi službeni i javni oblik muzealne ekspozicije djela likovnih umjetnosti u gradu Osijeku.

Trajanje izložbe zbog ratnih je okolnosti bilo kratko-zatvorena je već u proljeće I943. godine. Bio je to početak niza seljenja galerijske zbirke, što ih je Galerija proživjela s osječkim Muzejom unutar kojega je prvotno egzistirala, ali i poslije, nakon odvajanja i osamostaljivanja.

Tijekom ratnih i poratnih četrdesetih godina 20. stoljeća velik je broj umjetničkih djela u Muzej, odnosno u Galeriju u njegovu sklopu, ušao putem konfiskacije. U zbirku je I94I. ušao dio umjetnina koje su bile konfiscirane od imućnih osječkih židovskih obitelji, a djelovanjem KOMZA-e ${ }^{6}$ između r945. i I948. u Muzej je dopremljena velika količina umjetnina konfisciranih iz slavonskih vlastelinskih dvoraca. Reprezentativne umjetnine iz vlasništva slavonskih plemićkih obitelji na taj su način spašene od pljačke i uništenja, i vrijedan su temelj današnjih muzejskih zbirki. S povećanjem fundusa u Muzeju je 1947. postavljen osječki slikar i kipar Josip Leović kao kustos za tzv. galerijski materijal, a I949. kustos galerijske zbirke, odnosno zbirke slika i kipova postao je Jovan Gojković.

S obzirom na vrstu građe odnosno povijesno-stilske značajke umjetnina, prvotno zamišljenoj, Bauerovoj galeriji, doista je odgovarao naziv Moderna galerija, no taj naziv izgubio je smisao s dolaskom umjetnina iz bogatih plemićkih kolekcija, koje su velikom većinom bile iz I8. i ig. stoljeća.

Nakon I943. Galerija slika otvarana je i zatvarana nekoliko puta, na različitim lokacijama u Osijeku: I946. godine, kada je cjelokupni muzejski inventar preseljen u nekadašnju zgradu gradske vijećnice u Tvrđi, u zgradu u kojoj se Muzej Slavonije nalazi i danas; potom I948. godine, prvi put u vlastitoj, zasebnoj zgradi-autor tog postava, obogaćena novim akvizicijama, bio je Josip Leović; I95o. godine u reduciranom obliku, ponovno je u prostoru Muzeja Slavonije, pod naslovom Ioo godina osječkog slikarstua (I850.-I950.). Tu izložbu postavili su Josip Leović i Jovan Gojković, a izdan je i prvi katalog.
6 Komisija za sakupljanje historijskih spomenika, starina i knjižnica (KOMZA) formirana je neposredno po završetku Drugoga svjetskog rata pri Ministarstvu prosvjete NRH. 


\section{„Secesijsko razdoblje”}

Novo razdoblje $\mathrm{u}$ historijatu Galerije slika započinje fizičkim izdvajanjem iz Muzeja Slavonije 1952. te formalnim osamostaljenjem I954., a kulminira I964. konačnim preseljenjem u nov muzejski prostor, gdje se nalazi i danas.

Godine r952. Muzeju Slavonije Grad Osijek ustupio je za Galeriju prostor na prvom katu Županijske zgrade, u današnjoj Županijskoj ulici broj 4. Postav izložbe, otvorene 24. kolovoza I952. pod naslovom Razvoj slikarstua od kasne renesanse do polovice 2o. stoljeća, radili su Jovan Gojković i Josip Leović, uz stručnu pomoć Zdenke Munk. ${ }^{7}$ Bio je to reprezentativan, dotad najopsežniji izložbeni postav, s najvrednijim slikarskim djelima. Po Bauerovu mišljenju osječka galerija tada je ušla u red po fundusu najreprezentativnijih umjetničkih muzeja u zemlji. U prostoru Županijske zgrade Galerija je radila sve do I. kolovoza I955., a za nepune tri godine primila je oko 30.000 posjetilaca.

U Galeriji održao je Jovan Gojković brojna predavanja o umjetnosti, a kroz galerijski postav vodio je skupine posjetitelja; već je ranije Josip Leović školskoj djeci pri posjetu muzeju tumačio muzejske zbirke i vodio posjetitelje kroz postav-bio je to pionirski rad na području muzejske pedagogije u specijaliziranom (umjetničkom) muzeju u gradu Osijeku i šire. Radno mjesto muzejskog pedagoga u Galeriji prvi put je otvoreno I965. godine. ${ }^{8}$

Gojković je dao vrijedan doprinos u procesu pozicioniranja Galerije kao nove kulturne ustanove u gradu; bio je koautor njezina postava i priređivač kataloga, a likovno-pedagoškim radom pridonio je komunikaciji s publikom. Ipak, u procesu izdvajanja i osamostaljivanja Galerije ključnu je ulogu odigrala Danica Pinterović, tadašnja ravnateljica Muzeja Slavonije.

Drugoga veljače i954. Galerija slika u Osijeku izdvojila se iz sastava Muzeja Slavonije i postala samostalnom muzejskom ustanovom. Prvi vršitelj dužnosti ravnatelja bio je Jovan Gojković, do smrti I957. godine. Naslijedio ga je, od I958. do kraja I96o., povjesničar umjetnosti Drago Dodigović, a ig6I. v. d. ravnatelja Galerije postao je akademski kipar Stjepan Brlošić. ${ }^{9}$

\section{Europska avenija broj 9}

U jesen ig62. Galeriji je dodijeljena zgrada na tadašnjem Bulevaru JNA broj $9,{ }^{10}$ današnjoj Europskoj aveniji, čime je riješen dugogodišnji problem njezina smještaja-tamo se Muzej likovnih umjetnosti nalazi i danas. Prostorni kapacitet prizemlja i prvoga kata od $755 \mathrm{~m}^{2}$ bio je predviđen za stalne i povremene izložbe, za upravu i studijski rad, čuvaonicu za slikarsku, grafičku i kiparsku zbirku te za stolarsku radionicu i fotolaboratorij. ${ }^{11}$ Galerija slika otvorena je 20 . prosinca I 964 . godine, a u njezinom dvorišnom prostoru iste je godine inicijativom djelatnika Galerije postavljen Spomenik palim vojnicima 78. Šokčevićeve pukounije Roberta Frangeša Mihanovića. ${ }^{12}$
7 Za izložbu je tiskan i katalog, koji je priredio Jovan Gojković.

8 STJEPAN BRLOŠIĆ (bilj. 4), 24.

9 STJEPAN BRLOŠIĆ (bilj. 4), I5-I7.

Io Izgrađena u reprezentativnoj secesijskoj i historicističkoj arhitektonsko-urbanističkoj cjelini grada Osijeka, zgrada Galerije podignuta je I895. godine za Dragutina Neumanna, prema projektu arhitekta Josipa Vancaša.

II STJEPAN BRLOŠIĆ, Galerija slika u Osijeku, u: Osječki zbornik, Osijek, Muzej Slavonije, 8 (I962.), 374.

I2 Spomenik je I946. demontiran sa svoje izvorne lokacije u Osijeku i pohranjen u Gipsoteci u Zagrebu, a ı964. je na zahtjev Galerije slika vraćen u Osijek i postavljen u njenom dvorištu. Odande je premješten i I996. postavljen ispred zgrade osječkog Doma hrvatskih branitelja. DANIEL ZEC, Opaske uz pojedina djela Roberta Frangeša Mihanovića: primjer Zbirke kiparstva Muzeja likovnih umjetnosti u Osijeku, u: Imago, imaginatio, imaginabile: Zbornik u čast Zvonka Makovića, Lovorka Magaš Bilandžić; Dragan Damjanović (ur.), Zagreb, Filozofski fakultet Sveučilišta u Zagrebu, 2018., 366. 
U veljači ı966. godine Galerija slika u Osijeku promijenila je ime u Galerija likovnih umjetnosti u Osijeku. To će ime nositi sve do 20I4., kada ga mijenja u Muzej likovnih umjetnosti.

\section{Uloga institucije povijesti umjetnosti u gradu, regiji i nacionalnim okvirima}

Galerija, odnosno današnji Muzej likovnih umjetnosti, muzejska je ustanova prvorazrednoga značenja ne samo za likovnu kulturu grada Osijeka kao regionalnog središta nego i za hrvatsku likovnu umjetnost. Prema tipu muzeja i vrsti fundusa može se usporediti s nekoliko srodnih specijaliziranih umjetničkih muzeja u Hrvatskoj: s Muzejom moderne i suvremene umjetnosti u Rijeci, Galerijom umjetnina u Splitu i Umjetničkom galerijom Dubrovnik, s kojima ujedno dijeli ulogu središnjih regionalnih specijalističkih umjetničkih muzeja. Nadalje, fundus Muzeja likovnih umjetnosti komparabilan je, u smislu periodizacije pa i vrijednosti pojedinih djela, s predmetima u zbirkama drugih, većih, matičnih muzejskih ustanova nacionalnog značaja, primjerice Moderne galerije, Muzeja za umjetnost i obrt, Muzeja suvremene umjetnosti i Hrvatskoga povijesnog muzeja u Zagrebu. Kako je već istaknuo Vlastimir Kusik, „Osječki je muzej po nekim segmentima svoga fundusa ili pojedinačnim djelima superioran srodnim, pa i većim muzejima i galerijama, no jednako tako u pojedinim dijelovima fundusa postoje inferiornosti. Ono što je bitno, jest činjenica da njegov materijal kao cjelina, ili niz vrijednih pojedinačnosti, ima nacionalnu vrijednost."13

Današnji Muzej likovnih umjetnosti jedini je muzej specijalističkog tipa, odnosno jedini muzej koji se sustavno bavi prikupljanjem, istraživanjem, čuvanjem i prezentacijom isključivo djela likovnih umjetnosti od I8. stoljeća do suvremenosti, ne samo u Slavoniji kao najužoj regiji djelovanja nego u cijelom prostoru sjeveroistočne Hrvatske. Svojim fundusom, muzejskom djelatnošću i ulogom institucije povijesti umjetnosti, MLU je ponajprije usmjeren na likovnu baštinu regije, ali izlazi i izvan tih okvira. Temelj muzejskog fundusa čine djela koja imaju kapitalnu važnost za hrvatsku likovnu baštinu od sredine i8. stoljeća do danas, i po njima je osječki Muzej najpoznatiji i najpriznatiji. To se, ponajprije, odnosi na zbirke slika, koje su bile u vlasništvu slavonskih velikaških obitelji iz I8. i ı. stoljeća-na djela stranih majstora kasnog baroka, klasicizma i romantizma, koja ulaze i u srednjoeuropski kulturni korpus. Muzej, nadalje, posjeduje djela prve generacije hrvatskih pejzažista i portretista sredine Ig. stoljeća te djela na prijelazu u 2o. stoljeće i iz njegove prve polovine, kada se utemeljuje hrvatsko moderno slikarstvo. ${ }^{14} \mathrm{Tu}$ su i neka od antologijskih djela klasika hrvatske moderne (Vladimir Becić, Akt pred ogledalom; Bela Čikoš Sesija, Saloma i drugi). U Muzeju su, nadalje, zastupljeni svi osječki umjetnici te najveći dio njihova likovnog stvaralaštva, od nositelja osječke risarske škole, Huga Conrada Hötzendorfa i Adolfa Waldingera, pa do umjetnika koji su djelovali u prvoj polovini 20. stoljeća. Razdoblje druge
I3 VLASTIMIR KUSIK, Slikarstvo i kiparstvo XX. stoljeća ili osječki postav hrvatske moderne umjetnosti, $\mathrm{u}$ Tri stoljeća umjetnosti u Galeriji likounih umjetnosti Osijek, katalog izložbe, Osijek, Galerija likovnih umjetnosti, I998., 88.

I4 BRANKA BALEN, VLASTIMIR KUSIK, JASMINKA NAJCER SABLJAK, Tri stoljeća umjetnosti u osječkoj Galeriji, deplijan izložbe, Osijek, Galerija likovnih umjetnosti, 2007.

I5 DANICA PINTEROVIĆ, O razvoju osječkog muzeja, u: Osječki zbornik, Osijek, Muzej Slavonije, 6 (I958.), 7 . 
polovine 20. stoljeća i suvremena umjetnost još su, kako je to istaknuo Vlastimir Kusik, „bez željena opsega, ali nedvojbeno vjerodostojne kvalitete". No promišljenom politikom otkupa, po načelu otkupljivanja onoga što zaslužuje mjesto u stalnom postavu i onoga što se izlaže na povremenim izložbama, u nekoliko posljednjih godina Muzej se upotpunjuje djelima suvremene umjetnosti, čime je desetljećima oskudijevao.

Danas muzejski fundus broji 5734 muzejska predmeta raspoređenih u devet muzejskih zbirki: Zbirka slikarstva I8. i I9. stoljeća, Zbirka slikarstva prve polovine 2o. stoljeća, Zbirka slikarstva druge polovine 20. stoljeća, Zbirka crteža i grafika I8. i I9. stoljeća, Zbirka crteža i grafika prve polovine 20. stoljeća, Zbirka crteža i grafika druge polovine 20. stoljeća, Zbirka kiparstva, Zbirka plaketa i medalja i Zbirka novih medija. Sve zbirke registrirane su kao kulturno dobro Republike Hrvatske.

\section{Muzejsko-izložbena djelatnost}

Izložbeni program, kao najvidljiviji oblik djelovanja Muzeja likovnih umjetnosti, uporište ima u predstavljanju likovnih stvaralaca grada i regije, nacionalne baštine i suvremene umjetnosti te njegovanju međunarodne suradnje, posebno sa susjednim zemljama i inozemstvom u najširem smislu. Uz skupne i samostalne te tematske, monografske i retrospektivne izložbe Muzej kontinuirano, bijenalno i trijenalno, organizira tri velike likovno-izložbene manifestacije, koje su koncepcijski, organizacijski i produkcijski njegov izvorni i samostalni proizvod, i koje su postale svojevrsnim zaštitnim znakom njegova izložbenog programa: Slavonski biennale, Memorijal Ive Kerdića-Triennale hrvatskog medaljerstva i male plastike te Dani grafike.

Egzistiranje Muzeja, odnosno Galerije, kao samostalne muzejske ustanove obilježila su i tri različito koncipirana stalna postava, u kojima je konstantu činila građa I8. i I9. stoljeća, a mijenama je bio podložan materijal 20. stoljeća: stalni postav iz I952. pod naslovom Razvoj slikarstva od kasne renesanse do polovice 20. stoljeća, stalni postav iz I964. godine formiran po useljenju u novi prostor, te stalni postav iz I998. pod naslovom Tri stoljeća umjetnosti u osječkoj Galeriji. Uz prekide, taj je postav bio u funkciji sve do 20II. godine, kada je rasformiran.

Uz izložbe, nezaobilazno je istaknuti i izdavačku djelatnost Muzeja likovnih umjetnosti-monografske publikacije i publikacije koje su u obliku kataloga redovito pratile sve izložbene projekte i time postale važan prilog i dokument likovne povijesti grada, regije ali i nacionalne povijesti umjetnosti.

\section{Stručni i znanstveni doprinos djelatnika}

„Značaj bilo kojeg muzeja ogledava se u strukturi njegovih zbirki i u organizaciji naučnog i prosvjetnog rada kustosa, kojima su zbirke povjerene", napisala je i958. jedna od najvećih osječkih i hrvatskih muzealki, Danica Pinterović, u svom 
uvodu u historijat Muzeja Slavonije. ${ }^{15}$ Doista, njezina je misao odmjerena i dostojanstvena maksima kojom bi se neki muzej trebao voditi. Uz već spomenute djelatnike osječke Galerije, od Ig63. do danas svoj su obol stručnom, znanstvenom i pedagoškom radu ustanove dali, svatko na svoj način, ponajprije povjesničari umjetnosti. ${ }^{16}$ Neki od njih u Galeriji su kao kustosi proveli cijeli radni vijek, a nekih više nema među nama. Kronologijom dolaska u Galeriju, to su Ljiljana Sudić, Branka Balen ( $†$ ), Jelica Ambruš, Vlastimir Kusik ( $†$ ), Jasminka Najcer Sabljak, Valentina Radoš, Daniel Zec.

U posljednjih nekoliko godina broj je djelatnih kustosa u Muzeju likovnih umjetnosti znatno reduciran. Odlascima u mirovinu ili na druga radna mjesta, uz nepromišljeno vođenu kadrovsku politiku, danas je zapravo prepolovljen-sveden je na tek tri povjesničara umjetnosti. Gubitak stručnoga kadra težak je gubitak kako za unutarnje profesionalno funkcioniranje muzeja tako i za njegovu ulogu institucije povijesti umjetnosti-kao jednoga od generatora i ishodišta iz kojega proizlazi rad povjesničara umjetnosti. U konačnici, to je gubitak i za povijest umjetnosti kao znanstvenu disciplinu koja u ovome dijelu Hrvatske raspolaže vrlo malim brojem relevantnih stručnjaka: muzej poput ovoga nije samo mjesto za pohranu, čuvanje i izlaganje-on bi trebao prerasti u regionalni znanstvenoistraživački centar za likovnu umjetnost.

Ono što je za stručni i znanstveni rad u Muzeju Slavonije značila Danica Pinterović, za Galeriju likovnih umjetnosti bio je Oto Švajcer (1907.-2003.), iako nikada nije bio njezin kustos. Jer, ukoliko se osobama može pridati značenje institucije povijesti umjetnosti, onda je za grad Osijek i za Galeriju likovnih umjetnosti to bio upravo Oto Švajcer. Riječima Predraga Golla, „u ličnosti Ota Švajcera, najznačajnijeg istraživača kulture i likovne baštine, ponajviše slikarstva, grada i regije, Galerija je imala više od 50 godina svog istraživača, biografa i kroničara". ${ }^{17} \mathrm{Ili}$, kako je napisao Vlastimir Kusik: „U njemu je likovni život Osijeka, kako je duhovito kazao dr. Bogdan Mesinger, našao 'čovjeka instituciju', svog kroničara, kritičara, istraživača i tumača. (...) Jer, ako je Galerija mjesto u koje je smještena baština likovnog života grada Osijeka i dijela regije, Oto Švajcer je taj koji joj je dao ime i prezime, pa i više od toga, on joj je oblikovao tijelo našavši joj mjeru i udahnuo mu dušu davši joj smisao."18 Stopama Ota Švajcera išle su kustosice Galerije likovnih umjetnosti Branka Balen i Jasminka Najcer Sabljak-otišavši korak dalje od svoga prethodnika u istraživanju likovne baštine i8. i I9. stoljeća, otvorile su nova poglavlja naše povijesti umjetnosti. Jelica Ambruš monografski je obrađivala umjetnike Slavonije i Osijeka u 2o. stoljeću. Drugim smjerom išao je Vlastimir Kusik; kao kustos i muzejski savjetnik Galerije dugogodišnjim je djelovanjem ostavio svoj pečat u osječkoj likovnoj kritici, pridonijevši tumačenju i poznavanju hrvatskoga likovnog moderniteta i nadasve suvremenosti te Osijeka kao jednoga njihova stjecišta i izvorišta. Od šezdesetih (i prije) naovamo, svi oni na različite su načine, na različitim poljima djelovanja i u različitom opsegu, no iz osječke Galerije kao logističkog (i logičnog) uporišta, utjecali na profiliranje fizionomije povijesti
I6 Za specifično pedagoško djelovanje zaslužni su muzejski pedagozi: Marijanka Himelrajh, Mirjana Gorički i Ljiljana Habuš (od I965. do I970.), Leonilda Conti (od 20o6.) te Kristina Delalić Vetengl (od 20I5.).

I7 PREDRAG GOLL, Umjesto predgovora, u: Galerija likounih umjetnosti Osijek, monografija-zbornik, Osijek, GLUO, I987., 7 .

I8 VLASTIMIR KUSIK, Oto Švajcer i osječka Galerija, u: Oto Švajcer, Domaći i strani slikari XVIII. i XIX. stoljeća u Galeriji likounih umjetnosti Osijek, Osijek, Galerija likovnih umjetnosti, I988., 3. 
umjetnosti ovog dijela Hrvatske i formiranje znanja o njegovoj likovnoj baštini i suvremenoj umjetnosti-znanja kojim raspolažemo danas. O njihovu, kao i o stručno-znanstvenom i likovno-kritičkom djelovanju drugih kustosa ovoga muzeja, ali i brojnih uglednih povjesničara umjetnosti koji su kao vanjski suradnici surađivali s ovom ustanovom, rječito govore izložbe i katalozi, publicirani radovi i monografije, koje ustanova kao novo znanje proizvodi od I96o-ih do danas.

\section{K novom muzeju}

Novi naziv Galerije na početku novoga stoljeća promjena je što simbolično uvodi u znatno temeljitije promjene koje ustanovu očekuju u vrlo bliskoj budućnosti-promjenama što vode $\mathrm{k}$ novom muzeju, koji će djelovati u novom prostoru, s novim muzeološkim konceptom i s novim stalnim postavom.

Odluka promjene naziva muzejske ustanove vrlo je važna i dalekosežna te mora imati opravdanje i obrazloženje. Razlozi iz kojih je 20I4. donesena odluka promjene naziva, odnosno preimenovanja Galerije u Muzej likovnih umjetnosti čine se vrlo jednostavnima: u gradu Osijeku egzistira nekoliko galerijskih ustanova i galerijskih prostora koji nisu muzejskog, već isključivo galerijskog karaktera, a s kojima se Galerija likovnih umjetnosti pogrešno izjednačavala. Takva pogrešna percepcija nije odgovarala njezinu statusu najveće i najvažnije muzejske ustanove umjetničkog tipa u istočnoj Hrvatskoj. Galerija se naime nije, ponajprije kad je riječ o muzejskoj publici i medijima, zatim u krugovima izvan muzejske struke, a čak i unutar nje, percipirala kao muzejska ustanova, odnosno kao muzej umjetničkog tipa s vlastitim fundusom i misijom prikupljanja, čuvanja, zaštite, istraživanja i komunikacije likovne baštine. Poglavito zbog te specifične razlike, smatralo se da bi se promjenom naziva ustanove, odnosno zamjenom riječi galerija riječju muzej, instituciji pridao veći dignitet; točnije, da bi se time dokinulo identificiranje Galerije likovnih umjetnosti s drugim osječkim galerijama koje nemaju vlastitog fundusa, ali i utjecalo na promjenu stava i recepcije muzejske publike, odnosno društvene zajednice u cjelini, prema Galeriji i njezinu poslanju, a s konačnim ciljem veće posjećenosti. Osim promjene imena, sve drugo ostalo je isto; nije bilo strukturnih promjena ni preinaka muzejskog ustroja-novi muzej nije prešao u neki viši rang niti mu je povećan budžet. Posve je iskrivljena interpretacija da je Galerija promjenom imena prerasla $u$ muzej ili postala muzejom. Kako je izloženo na početku, postanak ovoga muzeja veže se uz I954. godinu, kada on funkcionira kao samostalna muzejska ustanova, odnosno muzej. No upitno je koliko će promjena naziva doista pridonijeti promjeni svijesti muzejske publike i lokalne društvene zajednice, njihovoj recepciji te konačno konzumiranju kulturnog proizvoda koji Galerija, odnosno Muzej, komunicira. Možda se više moglo postići promišljenijim aktivnostima u sferi odnosa s javnošću te edukacijom muzejske publike, dok promjena naziva ne mora, niti sama po sebi može, donijeti drastičnu promjenu. Pored 
toga, Galerija likovnih umjetnosti ipak je bila prepoznatljivo ime i osječki kulturni brend, kao što je to, primjerice, Moderna galerija u Zagrebu, ime koje se prepoznaje i ističe u nizu drugih, privatnih galerija, koje nisu muzeji, a djeluju u gradu i nisu joj konkurencija. Uostalom, neki od najvećih i najstarijih svjetskih umjetničkih muzeja danas u svojem imenu nose riječ galerija; na našem brendu trebalo je tek malo više marketinški poraditi.

Dok promjena imena pripada ipak isključivo semantičkoj razini, u godinama što slijede trebalo bi doći do znatno obuhvatnije i konkretnije promjene, presudne za budući rad Muzeja likovnih umjetnosti: ona se tiče planirane izgradnje nove muzejske zgrade.

Još je prilikom otvaranja Galerije Ig64. Antun Bauer konstatirao da je njezin novi prostor nedostatan za njezin fundus, značenje i potrebe, a danas je to više no očigledno. Prostorni kapaciteti zgrade u kojoj je Muzej smješten ne udovoljavaju više potrebama koje zahtijeva njezin današnji opsežan i dinamičan izložbeni program. Kustosi Muzeja danas se susreću s problemom nemogućnosti istodobnog funkcioniranja povremenih izložbi i stalnog postava, koji se morao skidati pri dolasku svake veće izložbe. Naposljetku je poglavito iz tih razloga Muzej i posve izgubio svoj stalni postav.

Nužno je obrazložiti intenciju gradnje dodatnog muzejskog prostora, odnosno još jednom naglasiti da je prostor historicističke gradske palače Neumann, u kojoj je Muzej likovnih umjetnosti smješten, nedostatan i neadekvatan za sve sadržaje kojima MLU danas kao muzejska, ali i galerijska institucija raspolaže i svojom djelatnošću komunicira. Već dugi niz godina taj je prostor s obzirom na muzejsku građu i izložbeni program prekapacitiran te više ne udovoljava zahtjevima nužnim da bi muzejska ustanova primjereno funkcionirala. Dva su goruća problema: prostor za stalni postav te prepunjeni depoi u kojima više nema mjesta za adekvatan smještaj rastućeg broja predmeta iz svih muzejskih zbirki. Oba problema bila bi riješena izgradnjom nove zgrade, kao interpolacije u dvorištu postojećeg objekta i s njom fizički povezane, a planirana je tijekom sljedećih nekoliko godina. Tako će stalni postav naći svoje mjesto u staroj zgradi, dok će u novoj dio izložbenog prostora biti namijenjen segmentu stalnoga postava u kojemu se predstavljaju djela suvremene umjetnosti, a dio postavljanju povremenih izložbi iz godišnjeg programa. Jednako važno, u projektu nove muzejske zgrade, koji udovoljava svim muzeološkim standardima, predviđeni su dovoljno veliki prostori za čuvaonice muzejske građe, ali i sve ostale muzejske sadržaje.

\section{(ㄷ) (1)}

Bilješka o osječkoj galeriji: od Galerije slika do Muzeja likovnih umjetnosti/Daniel $\mathrm{Zec} / \mathrm{CC} \mathrm{BY} / 4.0$

DoI: https://doi.org/ıo.31664/z4khpu.o6 